\section{TOWNSEND'S WARBLER AT SASKATOON}

\section{STANLEY J. SHADICK,} 810 Main St., Saskatoon, Sask.

At 1 p.m. on September 7, 1975, my attention was attracted by a brightly coloured warbler having a bath at our backyard waterfall. This waterfall is 3 feet high and drains into a goldfish pool. As it is only 10 yards from our back window it provides an excellent location for observing birds. Over the last 10 years the waterfall has attracted 23 of the 25 species of warblers previously recorded in Saskatoon.

My first impression was that it was an "unusually striking" Blackthroated Green Warbler. I called my mother, Mary Shadick, to have a look. I opened the field guide, "Birds of North America", to point out the field marks when I realized my identification was incorrect. The bird had a dark cheek, yellow breast and distinct black streaking on sides and throat. It was clearly a Townsend's Warbler, a species which breeds in the mountain regions of British Columbia and Alberta. I had previously seen it on two occasions in British Columbia. After a couple of minutes the warbler left and was not seen again.

This is the first record of this species for Saskatchewan. W. Ray Salt in "Alberta Vireos and Wood Warblers" states that the bird rarely wanders from the mountains. The most easterly record is of a male observed above the Rosebud River between Calgary and Drumheller on May 18, 1935. The Saskatoon report is approximately 300 miles further east.

\section{MIGRATING EAGLES - CADOMIN, ALBERTA}

PATRICK J. PAUL, c/o 10025 Jasper Ave., Edmonton, Alberta.

While working for the Alberta Provincial Government, I was following movements of Rocky Mountain Bighorn Sheep and hiked daily in the vicinity of Cadomin Mountain, several miles south-east of Cadomin, Alberta. Cadomin is about 150 miles west-southwest of Edmonton and just outside Jasper National Park.

On the 21 March 1976, I observed a pair of Golden Eagles hunting at approximately 6500 feet east of Cadomin Mountain and then work their way gradually westward. Although I was in the area for several hours more, no further birds were seen.

On the 22 March 1976, I was again in the area. From 1000 to 1400 hours I counted 106 eagles passing westward over Cadomin Mountain between 7500 and 10,000 feet, with the former altitude being more common. Early in the morning I observed what I assumed to be a pair of eagles hunting but after climbing up I decided that this was unlikely and what I had seen was probably an additional 15 eagles. Positive identification was made on approximately 25 birds and these were all adult Golden Eagles which leads me to believe that all were of the same species.

On the three days following 22 March, lone and paired eagles were sighted but they were infrequent and sporadic.

\section{SANDHILL CRANE REQUEST}

WANTED: Summer records of Sandhill Cranes in Saskatchewan and adjacent regions. Records of breeding and non-breeding birds in June and July, both historic and recent, are desired. Please send pertinent data to:

Dale Hjertaas

Dept. of Tourism \& Renewable Resources

Wild life Research Unit

2602 - 8th Street East

Saskatoon, Saskatchewan

S7H 0V7 